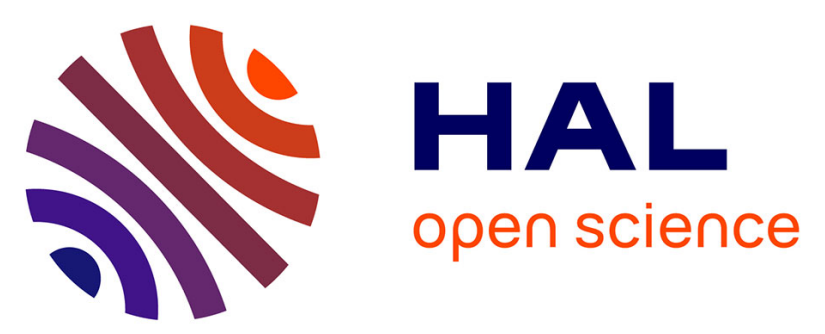

\title{
Scandal and Dialogical Network: What Does Morality Do to Politics? About the Islamic Headscarf within the Egyptian Parliament
}

Baudouin Dupret, Enrique Klaus, Jean-Noël Ferrié

\section{To cite this version:}

Baudouin Dupret, Enrique Klaus, Jean-Noël Ferrié. Scandal and Dialogical Network: What Does Morality Do to Politics? About the Islamic Headscarf within the Egyptian Parliament. R. Fitzgerald et W. Housley. Media, Policy and Interaction, Ashgate, pp.161-184, 2009. halshs-00489603

\section{HAL Id: halshs-00489603 \\ https://shs.hal.science/halshs-00489603}

Submitted on 6 Jun 2010

HAL is a multi-disciplinary open access archive for the deposit and dissemination of scientific research documents, whether they are published or not. The documents may come from teaching and research institutions in France or abroad, or from public or private research centers.
L'archive ouverte pluridisciplinaire HAL, est destinée au dépôt et à la diffusion de documents scientifiques de niveau recherche, publiés ou non, émanant des établissements d'enseignement et de recherche français ou étrangers, des laboratoires publics ou privés. 


\title{
SCANDAL AND DIALOGICAL NETWORK: WHAT DOES MORALITY DO TO POLITICS
}

About the Islamic headscarf within the Egyptian parliament

\author{
Baudouin Dupret, CNRS-ISP (Cachan) \\ Enrique Klaus, CEDEJ (Cairo) \\ Jean-Noël Ferrié, CNRS-PACTE (Grenoble)
}

This chapter aims at analyzing the mechanisms specific to the birth, the swelling and the dying out of the particular public phenomenon of the scandal, as it can be observed within an Egyptian environment. In the ordinary world, other people are constantly the object of normative assessments. When brought to the public, these evaluations give them their reputation, when positive, or make them fear to be discredited, when negative. Generally, the media constitute the means through which judgements concerning reputation take the dimension of a scandal. Sometimes, the scandal is relayed in official settings like the Parliament. We recently examined how a particular dialogical site, e.g. the Egyptian People's Assembly, the lower chamber of the Egyptian Parliament, can be part of the broader dialogical network of the scandal ignited by the Minister's statement, what we called the "Fârûq Husnî case" (Klaus, Dupret, Ferrié 2008). It is now possible to analyse the sequential organization, the categorization devices, the protagonists and the audiences implicated in the enfolding of a news item of this type, which transformed into a scandal and even in a public cause.

We proceed in three steps. First, we analyse the ordinary mechanisms of reputation and its breaches. We observe, in our material, how the structures of social and institutional life, like politeness, the protection of appearances, face preservation, but also their trial, like insults, humiliation and discredit, are achieved in action, through intertwined language games. Second, we describe how the mechanisms of ordinary reputation can be circumstantially mobilized to sustain, amplify and give credit to accusations, and therefore contribute to a generalization process giving to a singular blame the generic status of a scandal. Third, we scrutinize the functioning of a phenomenon which, although it does not exhaust the scope of all possible modes of the spreading out of scandals, constitutes a recurring and important figure: the moral over-investment of politics. We describe how questions related to moral relevance can be treated as such by members, but can also aim, without using explicit terms, at objectives belonging to the political repertoire.

This affair has its starting point with the statement the Egyptian Minister of Culture Fârûq Husnî made to the newspaper al-Misrî al-Yawm on 16 November 2006, in which he presented the headscarf as a sign of regression of the Egyptian society. This statement provoked a controversy opposing protagonists coming from political, religious and artistic milieus. Shortly afterward, it entered the precinct of the People's Assembly which was starting its annual session. The parliamentary debate proved fierce. Within a couple of days, the press multiplied accounts of both the debate and diverse personalities' stakeouts. Without ever officially apologizing, the Minister proposed a conciliatory solution consisting in the creation of a religious commission at the Ministry of Culture. Little by little, the crisis dried up and, after mid-December, it was almost forgotten.

\section{Good Press, Bad Press: Reputation in the Context of the Media and the Parliament}

While potentially containing intimate elements of a biography, reputation nevertheless remains a thoroughly public phenomenon. Reputation is with regard to the tribunal of the 
opinion what investigation is to the judicial court of justice. It is a kind of presumption about somebody else's identity with regard to a virtual public. Identity, in an interactional perspective, is the outcome of ascriptions and claims of ontological qualities ("I am", "you are", "s/he is"), a game of being and seeming, a "face" game, which is the object of constant negotiations, the object of a "face-to-face". Pragmatic linguistics was concerned with this issue in situations of co-presence. Brown and Levinson (1987) treated of it in their politeness model. In the turmoil of social relations, people strive to preserve their face; by so doing they threaten the other's face (face-threatening acts, FTA). They can also explicitly wish to affect him/her. Threatening, preserving and affecting are collaborative achievements. Brown and Levinson (1987: 69) summarize face-threatening strategies in the following chart:

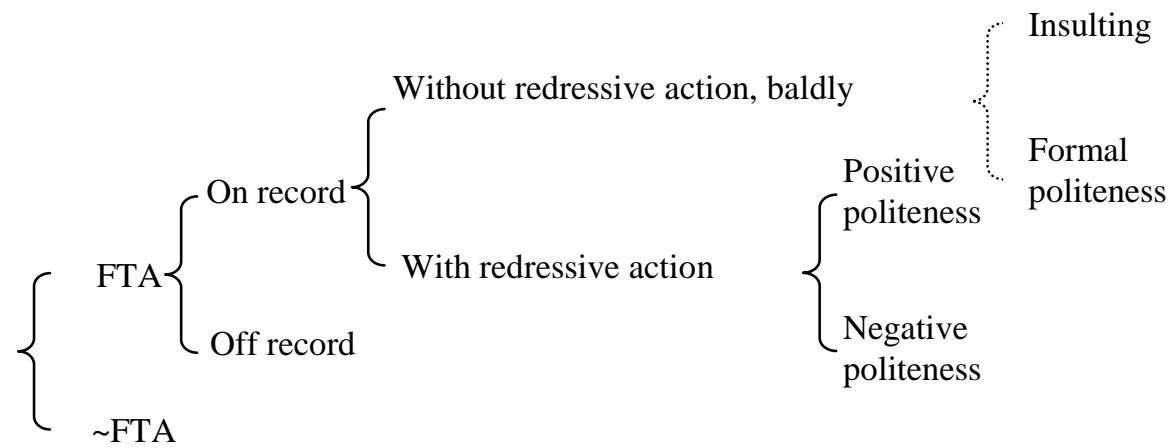

The chart describes a situation where something threatens somebody else's face. One can choose to act in an implicit way, with the benefit of not exposing oneself to the menace of discredit. One can also choose to act in an explicit way, in which case one might wish eventually to attenuate the consequences damaging for the other person or, on the contrary, not to care and to act in a blunt uncompromising way. If preserving someone else's face is at stake, one can also act so as to offer him/her a way out or not to make him risk ostracism. It seems to us that the Brown \& Levinson model is excessively idealistic when omitting to consider situations where threatening someone else's face is a goal in itself, in which case one casts insults, in a more subtle manner, one adopts a façade politeness (stippled brackets in the chart). Such strategy aims at maximizing discredit while preserving self-esteem. Insults can indeed be more degrading for their formulator than for their addressee.

Although the Brown \& Levinson model applies to face-to-face situations, it should not be discarded in situations where participants in the exchange are not physically gathered. Conversation analysis considers talk exchanges within a conversation as many speech-turns which articulation to one another must be analysed in a sequential manner. The notion of speech-turns must be understood, in its most ordinary sense, as a statement formulated by one co-present participant responding to a preceding participant. The idea of a dialogical network (Nekvapil \& Leudar 2002; Leudar \& Nekvapil 2007; Leudar, Marsland \& Nekvapil 2004) consists in extending the speech-turn system beyond situations of co-presence to all mediated exchanges. In other terms, the many parties to the exchange must not be physically gathered. Hence, the notion of a dialogical network allows stressing the networking of occurrences (press conferences, stakeouts, interviews) distant in time and space, mediatized and connected among each other thematically, interactively and argumentatively. We observe, through the analysis of our data on the Fârûq Husnî affair, in the press and in the parliamentary records that the face-threatening and preserving mechanisms of the Brown \& Levinson model remain effective in this type of network and can be applied to interactions separated in time and space. 
Actually, the whole dialogical network of the affair we concentrate on is rapidly set against the moral background of the Minister of Culture's reputation. This background is made of biographical elements related either to his sexual intimacy or to the performance of his function. Even before the parliamentary session, the alleged homosexuality of the Minister can be read between the lines in the press, like in this statement by Hamdî Hasan: "The Minister's ideas and his many provocative behaviours are something that his Lord only will judge" (Nahdat Misr, 18 November). When suggesting Fârûq Husnî's indecency, his detractors open the possibility for inferential judgements stemming from the disjunctive categorial mechanism opposing a minister (whose perversity is "well known") and the defenders of Islam (whose virtue are "above suspicion"). The rationale of the accusation shows how much it is not necessary to enter into the details of the reprobation object in order to allow the latter to express itself forcefully. Moreover, the allusive character of a categorization and the amplitude of the inferential repertoire it opens prove most efficient. It is even more damaging for the stigmatised person that inferences to be drawn against a moral background discretely sketched can grow up at the mercy of a random communicational dynamics.

It is also the possibility that his reputation as a homosexual affects his ministerial function that we can observe at the initial stage of this affair. So, Hamdî Hasan, continuing his declaration to Nahdat Misr (18 November), adds: "That he decides to make the Ministry of Culture adopt these principles and viewpoints, through his call to respectful work dedicated to keeping an open mind, this is what we oppose vigorously". In this statement, it is the categorial pair public-private which is mobilized to ground the Minister's illegitimacy to extend to his ministerial activity what belongs to his intimacy. This pair is embedded in an argumentative context aiming at separating the repertoires of action. In other argumentative contexts but in the same affair, it is exactly for converse purposes that the same pair can be invoked. This is the case, for instance, when the Minister is denied the right to make personal declarations for the reason that his responsibility as a public person cannot hide behind the personal character of some of his opinions.

In a more interactive way, the Minister's reputation is invoked and exploited throughout the parliamentary debates. It follows the same inferential scheme, starting with the questioning of the private person and ending with the denunciation of his public responsibilities. In the following excerpt, $\mathrm{Sa}^{\text {'d }}$ 'Abbûd starts with the reminder of Fârûq Husnî’s past declarations in which he explained his reticence vis-à-vis marriage:

\section{Excerpt 1: Parliamentary session, 20 November 2006 (verbatim)}

The Hon. S. 'A.'A.W. Qutb (Sa'd 'Abbûd)
$494 \quad$ Then, this way of behaving followed by this Minister has
$495 \quad$ antecedents, when he was publicly asked on the
$496 \quad$ television one day why he had marry nobody and he
$497 \quad$ answered "He who wants a glass of milk buys a cow". [These]
$498 \quad$ are words uttered by the Minister before. I understand them and
$499 \quad$ you understand them [as meaning that] he who wants to drink a
$500 \quad$ glass of milk has only to buy a cow. These words were used
$501 \quad$ before by this Minister's mouth [...]

Many times, e.g. during the TV episode referred to by the MP, the Minister's celibacy was cited as an incongruity asking for repair. Just focusing on this excerpt, we see how the reason for his celibacy he justifies with a kind of popular saying leaves open the range of possible interpretations and potential inferences concerning his sexual permissiveness. With a specific lexicon and the language games it authorizes, and through the use of an intertextual technique 
embedding the Minister's voice to better document the authority of the damaging inference, Sa'd 'Abbûd builds a background nimbus grounding Fârûq Husnî's marginality. Assimilating the wife to the cow and formulating the opinion that in sexual matters one has to look for what fits one's appetite, establish an inferential moral substrate regarding sexual orientations (heterosexual licentiousness, bisexual licentiousness, homosexuality) of the intended person.

Following up his intervention, the same speaker uses the description of the Minister's intimacy to affect his public activity:

\section{Excerpt 2: Parliamentary session, 20 November 2006 (verbatim)}

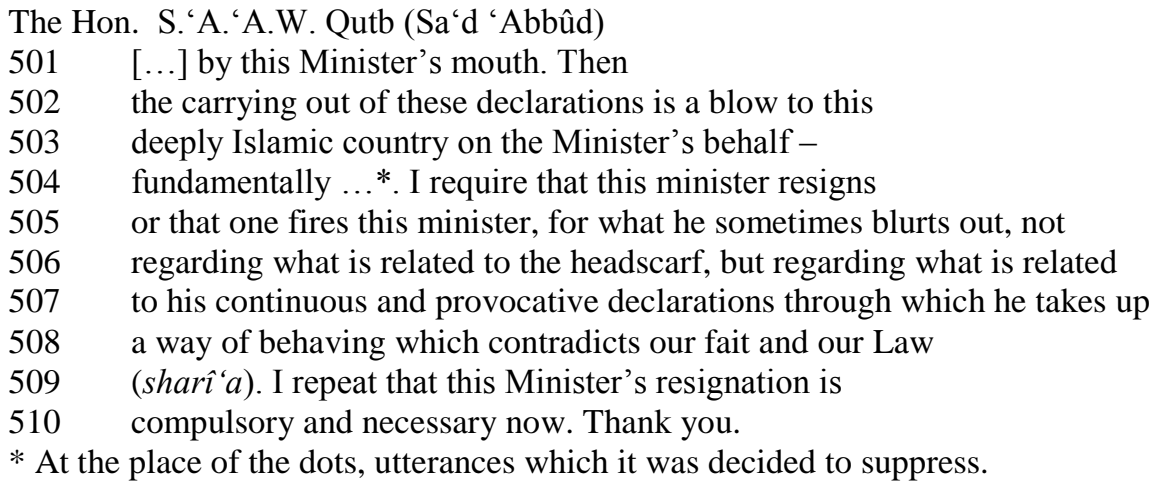

As we stressed when addressing press discourse, the public-private distinction is used but this time to refute the tightness divide between the two pair parts. It clearly appears that the semantic dimension of categorizations cannot be understood outside the context of their usage, that is, outside their pragmatics.

Blowing somebody else's face is an action which presents serious risks for those who perform it, since participants' faces are mutually and collaboratively vulnerable during the exchange (Brown \& Levinson 1987). Besides its deleterious character, insulting expose its undertaker to a whole set of retaliatory measures stretching from recording this precedent in his moral profile to ostracism. This is how journalists stress, in the press account of the parliamentary session, beyond the unexpected concord between majority MPs and Islamist minority MPs, the breach made to the etiquette ruling parliamentary activities: "What is new is the NDP's position ${ }^{1}$ who slaughtered the Minister and offered [his remains] to the [Muslim] Brothers ${ }^{2}$ in their offending attack against him" (al-Misrî al-Yawm, 23 novembre). Numerous commentaries and analyses depict scenes of lynching and killing to better express the virulence of Fârûq Husnî's discredit: "The scene was scarry and frightening. They were all brandishing their unsheatered swords in the midst of crispation, outbursts of anger and uproar. It was like you could not hear but the cries: 'Fârûq Husnî's head... Fârûq Husnî's head'... And actually the NDP's MPs made fall the Minister's head and brought it on an iron trail... to the Brothers" (R̂uz al-Yûsif, 22 Novembre). Or still: "And we decided to unwind on Fârûq Husnî, although it is known that he has clean hands and a fautless (nazâha) wealth, and that he was never, not even once, accused of corruption during his 20 years at the head of the Ministry of Culture. And this is not to defend Fârûq Husnî..." (al-Misrî al-Yawm, 22 novembre).

\footnotetext{
${ }^{1}$ National Democratic Party, i.e. President Mubârak's ruling party, which used to have always a majority above two thirds of the two chambers' MPs.

${ }_{2}^{2}$ Muslim Brothers constitute the principal opposition force within the Egyptian People's Assembly, although their political party is not legally recognized.
} 
It appears from these journalistic metaphors that, because of the argumentative constraint exerted on participants, critique cannot address the substance of the debate and must limit itself to its form. In other words, since it is utterly difficult for participants in the debate to retract on a series of topics concerning what is "Islamically correct" (what we called "negative solidarity" in Ferrié 2004), unanimity can only be by-passed through the critique of the violation of basic forms of civility and by compensating a blow made to one image by the show of another image to its advantage. There is a more fundamental dividing line which is drawn beyond the Minister of Culture's reputation, which opposes the partisans of a contrasted normativity, despite the fact that it cannot enfold in all its nuances within a parliamentary precinct characterized by procedural constraints and the negative-solidarity effects: "The Minister of Sins as he is called by the Muslim Brotherhood, 'the best Minister of Culture in Egypt's history' as he is described by leftist intellectuals, following the famous headscarf struggle. Here is the extreme contrast (tabâyun) between the Islamists' position and the leftist [personalities'], which grossly summarizes the fight which the Minister triggered among them" (al-Ahrâr, 4 Decembre).

\section{From Discredit to Scandal}

The mechanisms of reputation are in action in the specific contexts of media and parliaments. However, blows made to reputation remain usually confined within singular occurrences. It means that discredit rarely gets generalized. It is only occasionally that the ordinary-reputation mechanisms are mobilized to amplify accusations and to attempt shifting from a singular blame to the status of an affair drawing on a "scandalous" event. Three questions deserve here special attention: First, we observe the use of words which, taken in context, share a family resemblance common to the language games of the scandal; Second, we analyse how this language game structure itself in the practical grammar of a scandal process; Third, we describe how, according to the satisfaction of some "felicity conditions", a scandal process can be brought to a successful conclusion or, conversely and through various means, the generalization specific to this process can be impeded or inverted.

The Fârûq Husnî affair is by far not systematically characterized as a scandal. Often, it is about a controversy or a struggle. However, the terms used to speak of it share - to use Wittgenstein's expression (1965 and 1967) a family resemblance, which make them belong to the language games pertaining to the scandal, that is (to give some minimalist definition of the word), to a process of publicly denouncing a blow to moral norms (cf. also de Blic \& Lemieux 2005: 10). But even so, the practical grammar of words related to scandal is complex: there is no undifferentiated, indifferent to enunciation context, use of the word in its substantive (a scandal), predicative (a scandalous affair), verbal (to make a scandal), or adverbial (in a scandalous way) form. The words related to scandal have a major importance: on the one hand, an implicit and ordinary definition of the notion emerges from the family resemblance they share and the language games they allow; on the other hand, they function in a largely performative way: the use of these words create the blow to the norm as much as they reflect it. In the Fârûq Husnî affair, the very quick characterization of the events as the "struggle for the veil" (see excerpt 5, line 1) and their insertion in the newspapers front-page achieve the dramatization of the facts and their tying-up to the scandal family, together with demands, relayed by the press, for the Minister's excuses and sacking:

Excerpt 3: al-Misrî al-yawm, front-page, 18 Novembre 2006

1. The Struggle (ma'raka) Of the Veil Between Fârûq Husnî, the Brothers and the Sheikhs

2. [Facsimile of the first article, caption:] Picture of al-Misrî al-yawm's yesterday scoop article

3. Yesterday, the struggle of the veil broke out between, on one side, Fârûq Husnî, Minister of Culture, and, on 
4. the other side, the sheikhs and the Muslim Brotherhood. Declarations made the day before by the Minister to

5. al-Misrî al-Yawm on the topic of his rejection of the veil provoked various reactions. International press

6. agencies reported, from [what he said to] al-Misrî al-Yawm, the Minister's declarations, which provoked a

7. broad polemic on Islamic-oriented websites. Muslim Brothers launched a vast and forceful attack

8. against the Minister. Husayn Ibrâhîm, the deputy president of the Brotherhood group at the People's

9. Assembly, presented a memorandum to the Parliament, demanding from the President of the Republic the

10. Minister's sacking ( ' $u z l$ ). At the same time, Dr Hamdî Hasan, the group's official spokesman, presented a

11. request for urgent communication (bayân 'âjill) to the Prime Minister, in which he asks for the Minister's

12. excuses ( $i$ 'tizâr) and his sacking (iqâla). In parallel, intellectuals expressed their support to the Minister's

13. opinion. They consider the veil as a Wahhabi phenomenon, [which] they describe as a seed planted by Sadat

14. during the 1970 s to achieve political goals. They claim that this is a "wahhabization" of the Egyptian culture.

15. $[\ldots]$

A categorization conflict follows between the Minister's defenders and denunciators, or even among the defenders themselves. We have already stressed that the use of categories "allows members of a social group to produce inferences, judgements and justifiable ascriptions" (Dupret 2006: 399) concerning the social identity of things, people and actions (see also above). Knowledge is largely structured by categorizations, often organized in a paired way, to which types of activities, rights and duties are bound. In that sense, the choice of categorical descriptors has important consequences and is therefore the object of important conflicts. These conflicts often concern categorial pairs offering a morally consequential alternative to "categorizers". Thus, characterizing the veil as a "Wahhabi phenomenon" (excerpt 5, line 13) or as a "dress code" (Hamdî Hasan's statement in Nahdat Misr, front-page article, 18 November 2006) triggers immediately heavy consequences as to the identity of the person who chose one category or another (intellectuals vs. Muslim Brothers), to actions and commitments which can be expected from him (supporting the Minister vs. bluntly attacking him), to the right to take sides in the debate (illegitimate secularism vs. legitimate "state islamism"), to those on behalf of whom one claims to speak (non-representative minority vs. silent majority).

The words of scandal share, beyond their organization in categorial pairs, to concern a moral norm and to denounce the breach made to it (or the denegation of this breach). This is why they present some family resemblance: they relate to an act of designating a normative contradiction which gives reasons to be scandalized (de Blic \& Lemieux 2005: 20). So, in this case, the Minister's declarations are denounced as a "permissive backwardness", "irresponsible", contrary to the values of a "pious people", at war against "Islamic values", "rejectionist", "perverse", contrary to "the Constitution and the shari 'a", immoral, opposed to "the State's official religion" (al-Misrî al-Yawm, front-page article, 18 November 2006), indifferent to "the sources of legislation in Islam" (Nahdat Misr, front-page article, 18 November 2006), inflammatory (al-Karâma, 21 November), accommodating toward the West (Nahdat Misr, 21 November), or even the emanation of a "fifth column" (Nahdat Misr, 3 December).

The words of the scandal articulate in a language game which is specific to the denunciation of the public blow made to the moral norm. This game is sensitive to context and, in this sense it varies from one culture to another. De Blic and Lemieux (2005: 29) speak in that respect of a "set of shared and evolutionary expectations related to procedures to respect in order to denounce, judge and sanction in public". It means that language games are multiple and reflect forms of life which are culturally and praxiologically diverse, that is, they refer to communities of shared language and practices (Schulte 1992: 124-125). It is possible to describe the practical grammar and the usage conditions of these language games, i.e. "how

\footnotetext{
${ }^{3}$ This is the predicate used to refer to Saudi Arabia's conservative Islam.
} 
language, action and enunciation circumstances articulate to each other" (Schulte 1992: 118). Quoting Jeff Coulter (1989: 49): "Grammars reveal the manifold connections between kinds of expression and the sorts of circumstance within which and about which they may be used".

Establishing the practical grammar of the scandal leads thus to the description of the sequential organization of the different elements of a "scandal process". As the expression indicates, this process has a necessarily public dimension: it takes place in public and it addresses a public audience. It starts with the designation of a moral contradiction which is given some publicity by denunciating the violation of a shared norm and giving the reasons to be scandalized. This denunciation orients to an audience, although virtual, which it contributes to reflexively configure. Besides, by making visible the moral contradiction it supposes, the scandal process invites to the sanction (always public) of the culprit. However, it does not mechanically produce the repair to the moral breach it supposes: facts characterization can be contested and the object of the scandal can resist. Moreover, in its sequential logic, the scandal process can go through high and low tides, but it always runs into a close, either active (the sanction) or by default (the non-suit). Whatever the outcome, this process always concerns the identification and assessment of a collectivity's moral norms, therefore participating in their formation and transformation.

In this grammar of the scandal process, Garfinkel's article on degradation ceremonies (1956: 420-424) facilitates the analysis of morality-cognition mechanisms which are operating. Garfinkel defines status degradation as "any communicative work between persons, whereby the public identity of an actor is transformed into something looked on as lower in the local scheme of social types" (id.: 420). It is a work of disqualification and requalification, the criteria of which are the motivations scheme that is socially ascribed to the denounced person to explicate his action. The public denunciation, which triggers the denounced person's degradation, aims at destroying a social object in order to build another. Denunciation rhetoric often combines irony and the biographical re-examination of the denounced person. It also present a number of features: (1) the event and the denounced person seem to be out of the ordinary; (2) the blamed thing and the denounced person are placed within a scheme of preferences between general types which are assessed by referring to a dialectical counterpart; (3) the denunciator behaves so that he appears as a public figure acting as such; (4) the denunciator makes salient the supra-personal values of the "tribe" and achieves the denunciation in the name of these values; (5) the denunciator presents himself as invested of the right to speak in the name of these ultimate values; (6) the denunciator is perceived by witnesses as a supporter of these values; (7) the denunciator and the witnesses fix and perceive the distance that separates them from the denounced person; (8) the denounced person is ritually separated from the place he occupies in the legitimate order.

All these features are most explicitly found in the Fârûq Husnî affair: (1) the denounced person is a Minister whose profile is marked and atypical, whose political longevity is outstanding, and whose public stakeouts are original and non-consensual; the wearing of the veil belongs to sensitive issues in today's Egypt, it is the object of recurring attritions, and challenging its religious-obligation dimension constitutes an exception to the ordinary mechanism of negative solidarity; (2) it is indeed an event of a general type - the breach to the principles of the "True Religion" - which the denunciators make public; it is not only Fârûq Husnî who is under attack, but beyond his person, all this trend which is accused of despising religion and aping the West, even in its depraved values; the denounced event and person are not singularities, but the expression of a generic though minority trend; they are systematically placed as a dialectical counterpart of virtuous principles and models; in other words, the features of the scandal object can be read as symmetrically opposite to the honest 
citizen's; the Egyptian citizen is not given alternatives within a range of moral possibilities, but is compelled to make the choice of the veil if he wants to warrant his respectability; (3) denunciators always present themselves as public figures acting in their quality and not as individuals, as the statutory guardians of morality and not as people acting for personal reasons (i.e. as a sheikh, a MP, a Muslim Brother, a citizen, an upright journalist, a woman, an intellectual, moral, or religious authority, etc.); (4) denunciators keep on foregrounding the values common to Egyptians, among which prominently piety; Fârûq Husnî's declaration is denounced in the name of the virtue of al-Azhar's country ${ }^{4} ;(5)$ when claiming their own virtue and their institutional quality, denunciators constantly stress their right to denounce; they even make it a duty, that is, an obligation proceeding from the status they occupy; (6) journalists, when not themselves denunciators, act as witnesses to the fact that the denunciation finds its roots in these values which the denunciators are defending; (7) through the production of a distance between "them" (those who, like Fârûq Husnî, are deviant) and "us" (the virtuous people of Egypt and its representatives), denunciators draw a dividing line the crossing of which looks impossible; (8) Fârûq Husnî is constantly presented as unworthy of his charge, all the more because culture is a fixation around which the debate on "reislamization" is largely crystallizing; this de facto indignity implies demanding his de jure resignation; the denunciation aims at stressing the distance which currently makes it impossible that the Minister keeps his position in the legitimate order.

The transgression which is denounced in the scandal process goes hand in hand with the call for the perpetrator's sanction and degradation. In the press, it can take the following shape: "The Brothers demand the President of the Republic to fire Fârûq Husnî" (al-Misrî alYawm, front-page article, 18 November 2006). Within the People's Assembly, the conclusion of an 'Independant' MP's speech-turn constitutes another good example: "It's necessary that this Minister resigns and if the government shows self-respect, it should fire the Minister of Culture" (excerpt 6, lines 343-344). The demand for sanctions does lead to a successful conclusion in an automatic manner. The transgressed-norm characterization does not proceed in a linear way, but is the object, as we already saw, of contestations and attritions. Moreover, the scandal can, after having been made public, inflate or stagnate, according to the satisfaction of the denunciation felicity conditions. It is not so much about whether the denunciation is unanimous, but the denunciators' capacity to elevate the denounced thing and person to the rank of a social stake, to make it transform from a singular situation to a general case which can eventually get the status of a public cause. We shall be back to this issue, but it is for now enough to stress the contrasted nature of stakeouts in the 21 November edition of Nahdat Misr or the amplification effect of the first parliamentary debate of $20^{\text {th }}$ November (and its retake on the $22^{\text {nd }}$ ). In other words, it is the dynamics specific to the dialogical network of the affair which explains its evolution. As for its close, it works in our case through the transition from confrontation to negotiation. People speak of "defusing the crisis" and looking for "intermediary solutions" (Nahdat Misr, 25 November), of "reconciliation operation" (Akhbâr al-Yawm, 25 November), of "a dialogue characterized by frankness and openness" (al-Watan al-Yawm, 28 November). Let us notice that the moral norm in the transgression of which the scandal originates comes out strengthened from the process: the transaction does not concern its existence or its obligatory status, but the right of a Minister to take personal positions and to have on the norm a discourse at the margins of the consensus some morality entrepreneurs would like to promote. Nahdat Misr speaks of a Minister who "thinks about the formula proposed by Shihâb in the form of excuses for the evil that was cause by the [bad] interpretation of what he [said]" (3 December); and of a crisis which

\footnotetext{
${ }^{4} \mathrm{Al}$-Azhar is a historical mosque of Cairo and the main Islamic, university institution in Egypt.
} 
"ended without excuses", when the Muslim Brothers said they were satisfied with "the Minister [expressing] his respect toward veiled women" (4 December).

The scandal process may not produce the effects which were expected by its instigators. This is linked to the choice of the moral norm the breach of which is denounced. In order for the process to succeed, such norm must indeed be presented in a credible way as shared, even by those who do not adhere to it. In other words, it must be norm propitious to the mechanism of negative solidarity Jean-Noël Ferrié (2004: 122) defines as "the adoption of a common behaviour [which] does not proceed from the unanimous choice of everybody, but from the difficulty for anybody to express his disagreement". Such is the case in the Fârûq Husnî affair, in the sense that all the protagonists of the parliamentary debate - to confine ourselves to that setting - converge on the primacy of the religious reference ("Islamic religion is the religion of all civilisations. And progress doesn't mean to depart from the principles of Islam. Actually, progress means to remain bound to Islamic principles") and on the infraction perpetrated by the Minister ("I adjure President Mubârak to come to the rescue of Egypt's people and to fire the deviant Minister ...* who departed from what Islam requires, who departed from the Egyptian people's consensus"). Many participants posit the norm which is the object of the debate on the register of what is intangible ("The issue of the veil is not open to examination. It's a question which is settled for 1,400 years. It isn't today that we'll examine the veil issue. The veil issue isn't challengeable; it's an issue which is closed"). Obviously, this intangibility and the negative solidarity it creates are no matters of fact, but an achievement, the outcome of an argumentative endeavour of normalisation which progressively shrinks the space allowed for nuance and forces the expression of a façade consensus. Many excerpts of the parliamentary debate could be used to illustrate how any deviance vis-à-vis the axiological norm promoted by the denouncers is sanctioned by an interruption which places the speaker on the defensive and compels him to progressively get in line with the position of those who interrupt him. In a dynamics of successive sanctions imposing step by step the shrinking of the range of options open to the speaker, denouncers succeed in having the latter restrict himself to the minimum consensual, the content of which fitting the moral axiology promoted by the entrepreneurs of the scandal process because he had to step back in order to save his face.

The scandal process can also come to an end without the suggested sanction being implemented. The fact that Fârûq Husnî neither resigned nor was sacked does not mean in any way that the scandal process he went through failed. As Beaumarchais' quote goes, "if you speak ill of somebody, there will always remain something". Indeed, some effects of the scandal process related to the wearing of the veil will be perceptible later on; the scandal will be the object of retakes, in the same way it itself leant on the retake of former affairs which can be traced back at different points of the dialogical network enfolding. It is as much from the accumulation of processes of this type as from the violence or the acuity of one of them that some effect can proceed, be it expected originally or not. In Jon Elster's terms, one can speak of the indirect effects of actions undertaken for other purposes (Elster 1987). It is not sure that the entrepreneurs of the scandal process against Fârûq Husnî had really considered the possibility of his sacking. It appears that the sanction which is demanded by the denouncers does not necessarily constitute the goal of the scandal process they triggered or fed. The call for sanction is part of the grammar of the "scandalization", the end of which, in any case contingent and contextual, proceeds from a will of political participation that must be accounted for. 


\section{The moral over-investment of politics}

Although the political dimension of its trigger element is not initially obvious, the Fârûq Husnî dialogical network proves thoroughly political. The political tone goes through the whole network and it is mainly the participants in the network who give it this political dimension, in their quality of politicians for some of them, as aforementioned, but also through the mobilisation of this repertoire when intervening in Parliament and in the press.

The political repertoire indexing can noticeably be seen in the institutional inferences the participants in the debate mobilize. So, the latter call upon the government's responsibility and demand it collectively takes position: "Now, a Muslim Minister of the Egyptian government comes and attacks the veil. He must withdraw from the opinion he formulated. There must be a statement of the government and the Party against the Minister". It is in his quality of representative of the government within the parliamentary precinct that Mufîd Shihâb expresses himself about the affair: "In any case, I've to hurry and announce the [opinion] of the government, which makes me the honour to depute me to speak on his behalf. And I tell [you] that, on no account, the government shall accept the breach to the precepts of Islamic religion". As for the press, it does not omit to stress that the Prime Minister was late in taking position, as if it had to better mean that an official reaction was expected on an issue which had become politically consequential: "The Prime Minister, Dr Ahmad Nazîf, criticized the violent attack to which the artist Minister Fârûq Husnî was exposed. He repeated - two weeks after the veil affair broke out, in the calm after the storm of attacks against Husnî - that public personalities may give personal opinions in questions which do not pertain to their work" (al-Misrî al-Yawm, 30 November).

It is mainly via institutional inferences that participants can speak of a crisis and of lack of balance between the legislative and executive powers. So, when Fârûq Husnî's absence is noticed at the time of the parliamentary debate, it is the whole institutional system which is questioned and specifically the Assembly's right to control the government's activities: "I had hoped that a Minister who's responsible in our government presents himself before the Assembly and its members". The same critique is found in the opposition press: "The People's Assembly was effectively exerting its original competence (ikhtisâsuhu al-asîl) when interrogating the ministers. If ministers cannot be interrogated (musâ'ala) anymore, it would reflect the decline (ihdâr) of one of the most important means of the People's Assembly and the MPs' loss of their right [to exert their prerogatives]" (al-Jamâhir, 29 novembre).

Because the protagonists and the contexts are characterized in political terms, the stakes of the affair are presented as specifically political. This is why we can observe the participants concurring to impose their definition of these stakes, starting with the question of the official or unofficial character of the Minister's declarations. For some people, the blamed declarations have $a b$ initio a political dimension and reflect a more general trend of the government vis-à-vis Islam: "This is not a Minister's [stance], but we know this is the State's [stance] against the veil and against Islam's principles". For other people, it is a question of preserving appearances and not compromising the regime: "The National Party expresses its opinion and condemns these declarations". Originally, the characterization of the declaration as personal corresponded to the Minister's attempt at taming the damaging consequences of his statements being made public. In the same attempt at deflating the affair, NDP big shots tried to sort out issues according to their political importance and to relegate the "struggle of the veil" to the background: "This is why I ask the Honourable President and the honourable brothers and sisters members of the People's Assembly not to give this topic more importance 
than it deserves. Because we have questions of an extreme importance". In this context, President Mubârak's announcement of constitutional amendments was evoked by the Minister for Parliamentary Affairs: "How painful it is for me [to see] that our first working session [takes place] in this extreme tension. This, after we heard yesterday the important talk of Mister the President of the Republic. We're accomplishing a serious and critical work concerning the constitutional amendments and the laws". Others worry about the negative consequences of the Fârûq Husnî affair on the political agenda: "Some ministers warned against the fact that, if we don't contain the crisis rapidly, it'll lead to a critical deterioration of the government's position vis-à-vis public opinion, and the Brothers will get in considerable gain at a critical time before discussing constitutional amendments" (Nahdat Misr, 19 November).

Finally, among the political stakes of the affair as defined by the commentators, one finds numerous interpretations re-actualizing the issue of the Muslim Brothers' call for the building of an Islamic State: "What would happen if they [viz. the Brothers] did govern? Would the fate of those who formulate an opinion be to go to the scaffold?" (R̂uz al-Yûsif, 24 November); "They revealed, as the Brotherhood, a tyrannical [nature] endowed with a totalitarian ideology, which does not bear diverging opinions [...] If they did all this in the veil affair, what will they make of us if they accede to power?!" (Nahdat Misr, 19 November); "It is not about the veil affair, it is about the future of the civilian State, of civilisation, of history, of the acceptation of the other, of the necessity for Egypt, in the course of life, to remain itself" (Nahdat Misr, 22 November).

We see through these statements that the specific dispute which started with Fârûq Husnî's declaration amplified and eventually became something like the "Fârûq Husnî affair". Egyptian public life frequently witnesses this type of incidents. In the judicial context, we analysed many similar situations where a banal event crystallizes and gets publicly notorious (Dupret \& Ferrié 1997). In this sense, an affair means the taking by a singular and ordinary fact of a public and media-geared dimension. In turn, the affair takes a particular shape when, transcending the singular and personal dimension of the case, it is mobilized to sustain a cause of general concern.

Elisabeth Claverie (1994) shows how, in the Calas affair, Voltaire did not confer importance to Calas per se, but to the cause which he made him incarnate, i.e. the cause of humanity. The cause is thus the mobilization of general concern, above and outside particular interests, for the sake of "public good". It is a procedure taking pretext of a singular question projected into the public space to serve supporting the claim and defence of a certain conception of society's general ordering. Through a work of "denunciatory displaying" or "critical exhibiting" (Claverie 1994: 85), "entrepreneurs of morality" seek to inflect the substantial definition of the public, while using different institutional resources which are available to them and staying formally within the scope of sense and reference authorized by the authorities. In a certain way, the cause is thus the projection of a conception of society, public good and general interest, around which one seeks to proceed to a moral and normative mobilization. As for the affair, it is the starting point of a generalizing process and the opportunity of a generic positioning.

The dialogical network of the Fârûq Husnî affair is scattered with speech turns exhibiting its use for the purposes of a public cause, i.e. the cause of Islam and of its status within Egyptian State and society. During the parliamentary debate, Egypt's Islamic quality is constantly put forward: "Yes, we're an Islamic State. Yes, our Constitution stipulates that sharî' $a$ is the principal source of legislation. Yes, we're all Muslims. Yes, we all value 
Islamic religion, Islamic predication $\left(d a^{\prime} w \hat{a}\right)$, and Islam's principles. For all of us, our relationship to God - be He praised and exalted! - is the relationship of any zealous Muslim individual to his religion"; "We're in favour of Islamic sharî' $a$, of our veil, of the respectable people who represent us everywhere". In these excerpts, Egypt's Islamic character is not laid down in terms of confession or religious belonging stricto sensu. It is presented as a positioning or a commitment performatively taken when formulating these assertions.

During the parliamentary debate still, Egypt's Islamic character is equally presented in opposition to a non-Islamic otherness or externality: "Sharî' $a$ stipulates it, Islam stipulates it, and all Islamic countries confirm [the necessity] of the veil. Must I do myself as Europe or France which forbad the veil?!"; "What is attributed to the Minister is therefore external to alAzhar's Egypt, to Islamic Egypt, to the Islamic world". As soon as this virtuous islamicity is put forward, the cause of the defence of Islam steps in as a category-bound activity. The fact that defending Islam unfolds within the precinct of the People's Assembly has direct consequences on the way it is defended. MPs calling for Islam's defence orient to the rules of the institutional game: "I adjure President Mubârak to come to the rescue of Egypt's people and to fire the deviant Minister ...* who departed from what Islam requires, who departed from the Egyptian people's consensus"; "I urge the State's President to be the President of the Islamic State, that is, a Muslim President in al-Azhar's land, as well as I ask him to fire this Minister".

It was all the more necessary to elevate this singular dispute to the status of a cause that, symmetrically, the adverse camp (i.e. the camp that did not lean on this particular case to defend Islam) saw in the Islamic generalizing process the ground of a counter-cause. Although it would be wrong to oppose the Parliament to the press in this case, it is mainly, because of the pragmatic aligning of positions in the former and because of the argumentative constraint exerted on its members, in the column of the latter that one can track the formulation of the counter-cause: "It is not the affair of the veil, it is this of tolerance" (alMisrî al-Yawm, 24 November); "It is not the affair of the veil, it is this of political Islam in Egypt" (id.); "From niqâb $b^{5}$ to veil, via the call for the Ministers' killing and firing... this is the struggle of Islam's guardians in Egypt, and they are even more numerous, day after day, they raise their voice and prepare for their fight in the long term" (Nahdat Misr, 19 November). For the proponents of these counter-readings of the affair, the veil issue was perceived as a prerequisite, a first step before the advent of a political system wholly dominated by the Islamic reference. So, we see that, beyond the issue of the chastity of the female dress, moral stakes eventually become political.

Considering the explicit character of this affair, we find here another confirmation that participating in politics means striving for the definition of norms (Dupret \& Ferrie 1997). One of the means which are used to participate in power consists of appropriating a preexisting normative form, to substantiate it and thus to instate rules fixing normalcy and deviance. According to Howard Becker, this morality enterprise is grounded on three constitutive elements: initiative, publicity and interest. "Firstly, there must be somebody taking the initiative to make punish the supposed culprit; to implement a norm supposes thus a spirit of enterprise and implies an entrepreneur. Secondly, these who wish the norm to be implemented must draw the attention of others on the infraction; when made public, the latter cannot be neglected. In other words, there must be somebody shouting theft. Thirdly, in order to shout theft, there must be an advantage: it is personal interest which pushes to take this initiative" (Becker 1963: 145-146). In this context, the invention of the Islamic normative

\footnotetext{
${ }^{5}$ The niqâb is the veil which fully covers the face.
} 
tradition is embedded in a double move of power exercise and normative claim which, if analytically distinct, remains nevertheless phenomenologically indissociable:

\section{Excerpt 8: Parliamentary session, 20 November 2006 (verbatim)}

The Hon. K.H.M. Hasan (Karam al-Hifyân)

721 [...] What Mister the Minister of Culture

722 declared constitutes a

723 flagrant attack against $\operatorname{sharî}^{\prime} a$ and against the Constitution and

724 it constitutes a deviance from Islam and Islamic principles.

725 The legal rule (fiqhiyya) stipulates that there's no

726 interpretation of a clear text. As soon as the text has a

727 clear affiliation, one can't interpret it, either through

728 a personal opinion or a non-personal opinion.

729 The question of the veil belongs to the Islamic

730 principles which were stipulated in the Koran, the established Tradition

731 and the consensus of jurists (fuqaha $\left.\hat{a}^{\prime}\right)$ and imams. This is

732 why I consider it a great honour for Mister

733 the leader and the chief Muhammad Husnî Mubârak, for the majority’s

734 MPs and for the National Party to condemn

735 (nusammim) and to ask for the resignation of the Minister of

736 Culture. It'll strengthen the trust in the Egyptian

737 legislature, the government and the National Party

738 majority.

Prefacing his turn, the speaker characterizes the Minister's deviance regarding Islam, its principles and the Egyptian constitution which refers to them. Then, in one and the same token, the MP actualizes the authority of the norm and its substantiation by relating the veil to four normative bodies, i.e. the legal rule, the Koran and the principles it stipulates, the Prophet's Tradition, and the consensus among jurists and imams on this issue. In the same excerpt, one finds the three features identified by Becker in his definition of morality enterprise: publicity, through the debate which took place in the Parliament and in which the MP participated; the initiative to "to condemn and to ask for the resignation of the Minister" (lines 734-735); and the interest, both honorific ("a great honour" - line 732) and political, since, according to the speaker, achieving this initiative will "strengthen the trust in the Egyptian legislature, the government and the National Party majority" - lines 736-738). One can also notice the specifically political character of the interest to get from this morality enterprise. In this case, we stress the MP's granting of the morality-enterprise retribution to different instances of the ruling authorities: the President of the Republic (though silent in this affair), the MPs of the majority and the ruling Party. The same double claim of power exercise and norm ediction can be found in the speech of the Minister for Parliamentary Affairs: "At every step, in each of its legislations and decisions, the government sticks (multazima) to the precepts of our religion, considering that sharî' $a$, according to Article 2 of the Constitution, is the main source of legislation. All respect and all consideration (ijlâl) [are due] to the precepts of the Islamic religion, the main source of our legislation". Submitting to the norm appears as a governmental principle, a commitment (which is one of the possible translations of the term multazima) and an institutional constraint (according to Art.2 of the Constitution).

When the norm of reference is imposed, it becomes often impossible to contest its primacy, because of the mechanism of negative solidarity we already explained. Contrary to classical sociology which relates the plurality of values to the plurality of groups, we contend that we should better insist on the idea of persons embedded within the same space of references and playing, simultaneously, alternatively or concurrently, with values they share 
in common (Boltanski 1990: 81). Such lack of concurrence about norms of reference frequently initiates concurrence effects about the substantiation of norms and thus on their implementation. It is exactly in these terms that the press reacts, the day after the parliamentary session dealing with the Fârûq Husnî affair. Whereas NDP and Muslim Brothers MPs are known as political opponents, their will to fall into line with a virtual public opinion goes through moral overbidding: "History has nothing to do with Fârûq Husnî's opinion - and we disagree with him on this issue - but it concerns the phenomenon of ruling politics which bends over all storms and raises religious slogans" (Nahdat Misr, 21 November). Ruling party's MPs come to circumstantially espouse opposition's themes in order to secure their individual popularity (nevertheless necessary in the Egyptian electoral system) and to allow the party to which they belong escaping the disgrace ignited by one, important though marginal, of its members' declarations. Moreover, one should not totally ignore personal resentment of MPs, albeit from the NDP, vis-à-vis a Minister whose stances do not belong to the normalcy we formerly alluded to.

Although the scandal is triggered for itself, that is, in reaction to something considered as outrageous, it has the capacity to transform into a resource for political action, moral normativity being given the status of a major political stake. In a relatively closed system like in Egypt where there is no pluralism sorting out explicit political antagonisms, the many members share both rhetoric and values and struggle for the monopoly of their promulgation and implementation. Therefore, there is no concurrence on the conception of normativity, but on its performing ${ }^{6}$. As we already wrote about the Abu Zayd affair (Dupret \& Ferrié, 1997), the people who desire to participate in power must posit themselves in a controlled political locus, seek to profit from and exploit some potentialities by maximizing the opportunities it offers. This is what we mean by the moral over-investment of politics.

In the whole range of political action, there is one specific form (over)investing the repertoire of morality. Often, this form of action operates through the scandal. The detailed analysis of the Fârûq Husnî affair shows how, in Egypt, the moral repertoire can be largely invested by political actors who seek, by so doing, to bypass the fencing of public life. At the institutional level, this fencing is instantiated by the rulers' capacity to dodge any sanction of their action and management of public affairs, e.g. by cheating the polls. This fencing is observable in the fact that Egyptian political life finds its way within a double constraint: some channels which are explicitly political (like the alternation of rulers) are clogged; other channels are hardly practicable and are expensive for those who, individually or collectively, take them.

Because of these constraints and fencing, morality, which is already heavily invested in all political regimes, becomes particularly solicited. Its accessibility, its relative efficacy, and its cheaper cost belong to the explicative factors of this preponderance. Its accessibility is even stronger because of the domination of one reference, i.e. Islam, the political protagonists of which are constantly disputing the monopoly. As for the efficacy of the moral repertoire and henceforth its cheaper political cost, it proceeds from both the centrality of the reference to Islam in Egyptian public life and the specific tendency of morality to take the shape of Islamic normativity. Mobilizing the repertoire of Islamic normativity allows he who uses it to be assimilated with the "good" part of the contrastive and antithetical pair moral-immoral, relegating his detractors to the categorial otherness of moral deviance. Let us remind in that respect that it is the proper of any statutory degradation ceremony and thus of any political

\footnotetext{
${ }^{6}$ Note that it is not very different in an open system in which the ostentatious foregrounding of difference cannot hide the fact that it is often only a variation on the same theme.
} 
action using the repertoire of morality to make salient the group's supra-personal values, to initiate the denunciation in the name of these values, to ascribe oneself the status of proponent and defender of these values, and to claim to be invested of the legitimate right to talk in their name.

At least three figures of the moral investment of politics are observable in the Fârûq Husnî affair and testify to the equivocal character of the relations between politics and morals. The first figure is the moralization of politics, by which we mean these situations where some protagonists benefit from their position within the political game to denounce what they consider to be outrageous. In this case, although it is difficult or even impossible to document the participants' sincerity (which does not mean either that one should doubt this sincerity $a$ priori), the moral norm is exploited in itself and for itself, in order to secure its respect. In other words, politics is used to promote morality. In the two other figures, the equation is inverted: morality is used to better invest the field of politics and the moral repertoire becomes a repertoire of political action. These two inverted figures must be related to the fencing of public life as to the complicated use of some specifically political channels. It corresponds either to a cautious dodging of politics or to its re-characterization in non-directly oppositional terms. In the first case, one seeks to spare the cost of a direct political action. It is in that direction that heads the editor in chief of an opposition newspaper when noting that "it is easy to grip the government when entangled in a vice scandal, but harder to grip it in a corruption scandal" (al-Fajr, 27 November). The second case corresponds to these situations in which one seeks the full retributive and electoral profit of the use of the moral repertoire in politics. This is the meaning of one political commentator's remarks: "How to explain the NDP MPs' position? [...] I do not think that the NDP has a religious stance in that respect. Then, does the NDP MPs' revolution express personal positions regarding a personal opinion or does it [constitute] some political exaggerating of the kind which allows to become popular in the street? Answer: Generally, such is the position of NDP MPs. But how to explain this coordination which clearly appeared in the room of the People's Assembly among NDP MPs? This, it cannot be explained. Maybe does it proceed from the will of some people to make Fârûq Husnî fall and to use him as a scapegoat. Politics, as everybody knows, has no morals" (al-Misrî al-Yawm, 23 November). However, the two latter figures cannot be considered separately from the former in the enfolding of a scandal. The equivocal character of morals in politics stems from this.

The moral investment of politics is not the simple political use of morals. To say that the use of morals is part of strategies which can be documented, either in the parliamentary precinct or beyond, in the dialogical network the Minister of Culture's declarations ignited, does not mean that morals is just a means. It cannot be deduced from the opponents' investment in the building of a scandal that they use it in a simply manipulative way. Actually, the use of strategic resources does not implicate that the cause for which one uses them is itself a resource for other purposes. Parliamentary life and, more broadly, political life are so ordered that the game is played in a certain way and with certain resources. As stressed by Riker (1986), political life is an art of manipulation, but this is only a technical feature and not a cynical assessment of the manipulating people's beliefs and goals. It is possible to be a manipulator and to believe; to methodically and strategically proceed to establishing a fact and conducting a demonstration and to be nevertheless committed vis-à-vis this fact and the object of the demonstration, according to a conviction and not to an interest. The same holds true with strategy. To put it in a nutshell, means which are used for a political cause do not constitute a cause transformed into a political means. Besides, public interventions of MPs elected on a program of Islamic normativity conform so well to this program that it seems 
unnecessary to ascribe this conformity any cause but the program itself. Of course, some people among the promoters of the scandal may just consider it as a political means serving political interests. It would be the case of members of the majority wishing to "go popular". However, opportunist people are, by nature, secondary people and not promoters. Moreover, although they do not believe themselves in the values they defend, they believe that others believe in them and, in that sense, they believe in the efficacy of these values. Any staging, even strictly utilitarian, of these values contributes to increase this efficacy and to force the respect of those who believe in them only partly.

We have henceforth good reasons to think that opportunist promoters and users of the scandal act in this way, not because they have no other choice due to the political regime's nature, but mainly because the use of this repertoire of action directly proceeds from the reasons of their engagement in politics and from the analysis they make of the "public's" expectations. In that sense, they would do the same in a democratic context, since their motivation is moral and not strategic and since, when it proves strategic, it is grounded on the fact that they believe a minima that others have moral values and that they value their respect by the rulers. Thus, the moral repertoire is not initially selected because it allows doing politics indirectly in a context which does not permit it; it is foremost chosen for itself and indissociably for what it represents for the people. Nevertheless, it seems to fit the context, meaning that the rulers can hardly censor any public expression founded on it, because they cannot retract from values they proclaim themselves and because they believe, like their opponents and probably for the same reasons, that these values are largely shared. That the regime authorizes the expression of one type of values while censoring another does not implicate logically that the former was chosen ex ante because of this specificity. However, the evidence of its efficacy can further encourage ex post political actors to use it. Strategy is here the heir of morals.

\section{References}

Becker, Howard (1963) Outsiders Glencoe: The Free Press

de Blic Damien \& Lemieux Cyril (2005) "Le scandale comme épreuve : éléments de sociologie pragmatique $\gg$ Politix $\mathrm{n}^{\circ} 71$

Boltanski Luc (1990) L'Amour et la Justice comme compétences Paris : Métaillé

Coulter Jeff (1989) Mind In Action, Atlantic Highlands, NJ : Humanities Press International

Dupret Baudouin (2006) Le jugement en action: Ethnométhodologie du droit, de la morale et de la justice en Égypte, Geneva: Droz

Dupret Baudouin \& Ferrié Jean-Noël (1997) «Participer au pouvoir, c'est imposer la norme : sur l'affaire Abu Zayd (Egypte, 1992-1996)», Revue Française de Science Politique, 47/6:762-775

Dupret Baudouin \& Ferrié Jean-Noël (2007) "The Audience They Assign Themselves: Three Arab Channels and Their 'Self-Presentation' (al-Jazeera, al-Manar, al-Hurra)', Ethnographic Studies n ${ }^{\circ}$ : 63-80

Dupret Baudouin \& Ferrié Jean-Noël (2008) "News Headlines: Stating in Brief what is Relevant in Today's World (al-Arabiya, al-Jazeera, al-Manar, BBC World)", Ethnographic Studies $\mathrm{n}^{\circ} 10:$ 49-68

Elster Jon (1987) Le Laboureur et ses enfants. Deux essais sur les limites de la rationalité, Paris: Minuit

Ferrié Jean-Noël et Dupret Baudouin (2007) «La danseuse du ventre et son double : scandale et jeux de catégorisation en Égypte », Quaderni 63: 97-108 
Ferrié Jean-Noël (2004) Le régime de la civilité. Public et réislamisation en Egypte, Paris: Presses du CNRS

Garfinkel, Harold (1956) "Conditions of successful degradation ceremonies." American Journal of Sociology 61, 5: 420-424

Leudar Ivan \& Nekvapil Jiří (2007) "The War on Terror and Muslim Britons' Safety: A Week in the Life of a Dialogical Network" Ethnographic Studies n9: 44-62

Leudar Ivan \& Nekvapil Jiří (2004) "Media networks and political argumentation", Journal of Language and Politics 3:2

Leudar Ivan, Marsland Victoria \& Nekvapil Jiří (2004). "On membership categorization : 'us', 'them' and 'doing violence' in political discourse”, Discourse \& Society, Vol. 15 (2-3) : 243-266

Nekvapil Jiří \& Leudar Ivan (2002) "On Dialogical Networks: Arguments about the Migration Law in Czech Mass Media in 1993" in Hester S. \& Housley W. (éds.) Language, Interaction and National Identity, Aldershot: Ashgate

Riker William (1986) The Art of Political Manipulation New Haven: Yale University Press

Sacks Harvey (1995) Lectures on Conversation, Oxford: Blackwell

Schulte Joachim (1992) Lire Wittgenstein. Dire et montrer (trad. par M. Charrière et J.P. Cometti), Combas: Editions de l'éclat

Wittgenstein Ludwig (1965) Le Cahier bleu et le Cahier brun (traduction G. Durand), Paris: Gallimard

Wittgenstein Ludwig (1967) Philosophical Investigations (traduction par G.E.M. Anscombe), Oxford \& Cambridge: Blackwell 